\title{
DISTINÇÃO DE \\ GÊNERO PARA FINS DE \\ APOSENTAÇÃO E TUTELA \\ JURÍDICA DAS PESSOAS \\ TRANSSEXUAIS
}

GENDER DISTINCTION FOR THE PURPOSE OF RETIREMENT AND THE LEGAL PROTECTION OF TRANSSEXUAL PERSONS

DISTINCIÓN DE GÉNERO PARA FINES DE JUBILACIÓN Y TUTELA JURÍDICA DE LAS PERSONAS TRANSEXUALES

\section{Matheus Silva de Freitas ${ }^{1}$ Jonathan Barros Vita²}

Resumo: O presente artigo, sustentado nos pilares da hermenêutica constitutional, teoria tridimensional do direito e diálogo das fontes, teve como foco de análise o tema dos direitos previdenciários das pessoas transexuais, estruturado nos dois primeiros capítulos através do método dedutivo, analisando o gênero sex-

1 Mestrando em Direito pela UNIMAR-SP, no Município de Marília, Estado de São Paulo, Brasil. Graduado em Direito pela Universidade Católica de Pelotas/RS. Tabelião de Notas e Oficial de Registro Civil das Pessoas Naturais no Estado de São Paulo. Endereço eletrônico para correspondência (e-mail): cartfreitas@gmail.com.

2 Especialista em Direito Tributário pelo Instituto Brasileiro de Estudos Tributários - IBET-SP, Mestre e Doutor em Direito do Tributário pela Pontifícia Universidade Católica de São Paulo - PUC-SP e Mestre em Segundo Nível em Direito Tributário da Empresa pela Universidade Comercial Luigi Bocconi - Milão - Itália. Advogado, Consultor Jurídico e Contador. Coordenador e professor do Mestrado em Direito da UNIMAR-SP, no Município de Marília, Estado de São Paulo, Brasil. Eletrônico para correspondência (e-mail): jbvita@gmail.com. 
ual como elemento integrante do estado civil individual da pessoa humana, tal como o conceito, as características e a repercussão jurídica decorrente da transexualidade, incluído o estudo acerca do entendimento Jurisprudencial contemporâneo sobre a possibilidade de alteração civil do gênero sexual e, no terceiro capítulo, formulado através do método hipotético-dedutivo, focalizado no objetivo de resolver a problemática do direito à aposentadoria (por idade e tempo de contribuição) dos transexuais que tenham alterado o seu sexo constante do Registro Civil da Pessoa Natural e, ao final, trazendo duas soluções que acreditamos sejam aptas, material e formalmente, a resolver a repercussão jurídica previdenciária decorrente da alteração civil do gênero sexual.

Palavras-chave: Aposentadoria. Identidade de gênero. Transexualidade.

Abstract: This article, based on the pillars of constitutional hermeneutics, three-dimensional theory of law and dialogue of sources, focuses on the issue of the social security rights of transsexual people. The first two chapters are structured using the deductive method, analyzing sexual gender as an integral element of the individual civil status of the human person, such as the concept, characteristics and legal repercussions of transsexuality, including the study of the contemporary Jurisprudential understanding of the possibility of civil alteration of sexual gender. The third chapter is formulated through the hypothetical-deductive method, and focuses on resolving the problem changed the right to retirement (by age and time of contribution) of transsexuals who have altered their gender in the Civil Registry of Natural Persons. Finally, we offer two solutions that we believe are capable, materially and formally, to resolve the legal repercussions of social security resulting from a civil change of sexual gender.

Keywords: Retirement. Gender identity. Transsexuality.

Resumen: El presente artículo, apoyado en los pilares de la hermenéutica constitucional, teoría tridimensional del derecho y diálogo de las fuentes, tuvo como foco de análisis el tema de los derechos previsionales de las personas transexuales. Fue estructurado en los dos primeros capítulos a través del método deductivo, analizando el género sexual como elemento integrante del estado civil individual de la persona humana, tal como el concepto, las características y la repercusión jurídica decurrente de la transexu- 
alidad. También está incluido el estudio acerca del entendimiento jurisprudencial contemporáneo sobre la posibilidad de alteración civil del género sexual. En el tercer capítulo, formulado a través del método hipotético deductivo, focalizado en el objetivo de resolver la problemática del derecho a la jubilación (por edad y tiempo de contribución) de los transexuales que hayan alterado su sexo tal como consta en el Registro Civil de la Persona Natural y, al final, aporta dos soluciones que creemos que son aptas, material y formalmente, para resolver la repercusión jurídica previsional decurrente de la alteración civil del género sexual.

Palabras clave: Jubilación. Identidad de género. Transexualidad.

\section{INTRODUÇÃO}

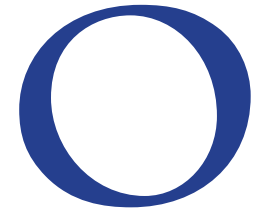

respeito à diversidade e o dever ético-jurídico de construção de uma Sociedade sem preconceitos, fraterna, livre e materialmente igualitária assumiram a condição de valores jurídicos fundamentais na pós-modernidade, conforme, ressalte-se, se depreende do Preâmbulo 3 da Constituição Federal de 1988, dotado de força hermenêutica irradiante para todo ordenamento, à luz da eficácia direta dos princípios por ela encartados 4 . A proteção suprema à liberdade existencial (Art. $3^{\circ}$, Art. $5^{\circ}$, caput, e incisos II, IV, VI, VIII, IX, X, XIII, XIV, XV, XVI, XVII, CF), à vida digna (Art. 50, caput, 170, 227, CF), à intimidade e vida privada (Art. $5^{\circ}$, incisos X, XI, XII, CF) corrobora a sedimentação da tutela à autonomia privada, igualdade material, pluralismo e não discriminação, elementos essenciais à tutela da dignidade.

E nesse contexto, a partir da segunda metade do século passado, com essa mudança jus-filosófica a Sociedade e, com efeito, o Estado (Legislativo, Executivo e Judiciário) e aplicadores do direito passaram a também se preocupar com a

3 PREÂMBULO. Nós, representantes do povo brasileiro, reunidos em Assembleia Nacional Constituinte para instituir um Estado Democrático, destinado a assegurar o exercício dos direitos sociais e individuais, a liberdade, a segurança, o bem-estar, o desenvolvimento, a igualdade e a justiça como valores supremos de uma sociedade fraterna, pluralista e sem preconceitos, fundada na harmonia social e comprometida, na ordem interna e internacional, com a solução pacífica das controvérsias, promulgamos, sob a proteção de Deus, a seguinte CONSTITUIÇÃO DA REPÚBLICA FEDERATIVA DO BRASIL.

4 MENDES, Gilmar Ferreira; BRANCO, Paulo Gustavo Gonet. Curso de Direito Constitucional. São Paulo: Editora Saraiva, 2012, 86-87. 
defesa da dignidade de pessoas antes excluídas de tutela jurídica, muitas vezes tratadas como formalmente desiguais perante a Lei, e que tinham a sua esfera de liberdade existencial restringida ou até completamente suprimida.

É o caso da proteção aos direitos dos afrodescendentes, mulheres, homossexuais, transexuais, deficientes físicos e mentais, dentre outros, cada vez mais se buscando - concretamente - a proteção desses seres humanos antes (ou ainda hoje) vítimas de ilegítima discriminação, opressão e falta de tutela jurídica, seja através da mudança paulatina do consciente coletivo, seja em razão dos Tratados internacionais e normas internas tendentes a tutelar essas questões que impulsionam a aceitação social.

A luz desses valores, no ano de 1960 - através da Lei n 3.807/1960 - Lei Orgânica da Previdência Social, visando compensar a menor inserção das mulheres no mercado de trabalho, instituiu-se um tratamento jurídico previdenciário pautado na distinção entre homens e mulheres, com fixação de períodos aquisitivos distintos entre os sexos para fins de concessão dos benefícios de Aposentadoria por velhice (hoje equivalente a aposentadoria por idade) e tempo de serviço (hoje equivalente a aposentadoria por tempo de contribuição). Esse mesmo tratamento discriminatório, na exata proporção em que originariamente instituído, teoricamente pautado em fundamento de isonomia material, permanece tutelado pela Constituição Federal em vigência (Art. 201, §7º, incisos I e II, CF).

Aos dias atuais, seguindo a linha evolutiva de tutela concreta da dignidade da pessoa humana, individual e socialmente considerada, tem-se buscado, com apoio da evolução da Medicina, encontrar meios jurídicos aptos a resolver a problemática das pessoas reconhecidas como transexuais, que são objeto de grave exclusão social decorrente da sua condição de inadequação entre o sexo biológico e a identidade sexual, o que legitimou o Conselho Federal de Medicina e Ministério da Saúde a regulamentarem os procedimentos necessários à realização do tratamento destinado à mudança artificial do sexo, e amparando, nessa toada, a formação de precedentes jurisprudenciais que caminham no sentido de reconhecer a essas pessoas o direito de ter promovida a alteração do seu estado civil, em decorrência da mudança do nome e sexo compatíveis à identidade de gênero, com a consequente Averbação dessa mudança no Assento 
de Nascimento constante do Registro Civil das Pessoas Naturais (RCPN).

Consoante irá se aprofundar o estudo no decorrer do trabalho, a alteração do gênero sexual da pessoa (enquanto elemento integrante do estado civil) não tem sua repercussão jurídica adstrita pura e simplesmente no direito ao nome, proteção da liberdade sexual e estabelecimento dos vínculos familiares, mas sim interfere em toda e qualquer espécie de relação jurídica em que o gênero sexual da pessoa possa ocasionar tratamento jurídico diferenciado, tenha a relação jurídica cunho civil, tributário, trabalhista, administrativo, previdenciário, etc.

Exsurge, aqui, o objetivo central deste trabalho, qual seja, analisar o tratamento jurídico previdenciário - nas modalidades de Aposentadoria por idade e tempo de contribuição - a ser dado às pessoas que promoveram a alteração do seu sexo biológico, para assumir a condição civil de detentora de gênero sexual diverso.

Diante do caráter recente da orientação Jurisprudencial que passou a admitir a alteração do gênero sexual da pessoa, com a consequente Averbação da mudança do sexo no Assento de Nascimento constante do RCPN, ainda não se vislumbra a formação de precedentes Jurisprudenciais, orientação Administrativa do Instituto Nacional do Seguro Social (INSS), tampouco estudo doutrinário que aprofunde a análise acerca da matéria, denotando a pertinência e a atualidade da abordagem a que se propõe no presente artigo.

Sob esse contexto, buscar-se-á, à luz de uma interpretação sistêmica do ordenamento, alicerçada em exercício hermenêutico pautado na teoria tridimensional do direito ${ }^{5}$, na hermenêutica constitucional ${ }^{6}$, teoria do diálogo das fontes ${ }^{7}$, além da primazia da tutela da dignidade da pessoa humana, e sem descurar do exato fim perquirido pela norma (Art. $5^{\circ}$, Lei de Introdução às Normas do Direito Brasileiro - LINDB), encontrar soluções razoáveis a serem aplicadas às pessoas transexuais que promoveram a alteração civil do gênero sexual, para fins do tratamento previdenciário a ser dado especificamente nas modalidades de alteração das características do próprio corpo, tal como o sexo civil da pessoa, como elementos integrantes dos direitos da personalidade e, no segundo, analisando

5 REALE, Miguel. Teoria tridimensional do direito - situação atual. 5. ed. São Paulo: Editora Saraiva, 1994.

6 BARROSO, Luís Roberto. Interpretação e Aplicação da Constituição. 3. ed. São Paulo: Editora Saraiva, 1999.

7 MARQUES, Cláudia Lima. Diálogo das fontes. Do conflito à coordenação de normas no direito brasileiro. 1. ed. São Paulo: Editora RT, 2012. 
o conceito, elementos e características da transexualidade, identidade e gênero sexual à luz das teorias binária e ternária, e a possibilidade de alteração civil do sexo da pessoa à luz do posicionamento jurisprudencial contemporâneo. Abordase, ao final do segundo capítulo (Tópico 2.2), a natureza jurídica da Sentença que autoriza a mudança do gênero sexual, tal como a repercussão dos seus efeitos.

O terceiro Capítulo, estruturado pelo método hipotético dedutivo, buscará traçar uma análise concreta acerca do Sistema previdenciário brasileiro, focalizando nas modalidades de aposentadoria por idade e tempo de contribuição, abordando o fundamento jurídico que - teoricamente - legitima a distinção de tratamento entre homens e mulheres para fins previdenciários, e analisando com profundidade os efeitos que essa discriminação legal acarretará às pessoas que alteraram o seu gênero sexual, encontrando-se - à luz de uma compreensão global do ordenamento jurídico brasileiro - quatro possíveis soluções gerais hipotéticas aptas a resolver o tratamento previdenciário a ser dado aos transexuais (Tópico 3.2).

Ao final desse terceiro Capítulo, através dos subtópicos 3.2.1 e 3.2.2, concentrarse-á o estudo a acerca das possíveis Soluções, que aptas a conferir adequado tratamento jurídico previdenciário às pessoas que promoveram a alteração civil do gênero sexual.

Por fim, o quarto e último Capítulo se cingirá na compilação das conclusões centrais extraídas através do presente artigo, com a pontuação cronológica das premissas fáticas e jurídicas que respaldam as propostas de solução ao tratamento previdenciário a ser dado aos transexuais que promoveram a alteração civil do gênero sexual, tenham eles adotado a concepção binária ou ternária de gênero.

DOS DIREITOS DA PERSONALIDADE - CONSIDERAÇÕES ELEMENTARES

\section{CONCEITO E DEFINIÇÃO}

As matérias atinentes à transexualidade e à redesignação de gênero estão inafastavalmente ligadas aos direitos da personalidade, material e formalmente, 
em que pese suas repercussões jurídicas sejam amplas, e interfiram no âmbito das relações familiares, trabalhistas, previdenciárias, além de outras matérias.

Sem se debruçar na controvérsia acerca do seu início, à luz das teorias que a justificam (concepcionista e natalista) ${ }^{8}$, fulcradas na exegese dos Arts. $1^{\circ}$ e $2^{\circ}$ do Código Civil pátrio, a personalidade pode ser conceituada como atributo inerente à existência do indivíduo, decomposta pelo conjunto de elementos que a integram, nas suas acepções físicas (vida, integridade física e psíquica, indisponibilidade relativa e direito ao próprio corpo), morais (nome, honra, reputação, imagem, intimidade, vida privada) e intelectuais (liberdade de pensamento, expressão, manifestação, direitos autorais, propriedade intelectual) ${ }^{9}$, e da qual decorre a capacidade, de direito (gozo) e exercício (de fato $)^{10}$.

Os direitos da personalidade devem ser interpretados uniforme e sistematicamente (vide, inclusive, o Enunciado $n^{\circ} 274$, da Jornada de Direito Civil do Conselho da Justiça Federal), para, então, extrair-se o real sentido de suas positivações, todas de crucial relevância à concreção da dignidade da pessoa humana, sem sobrelevar a aplicação de uma regra em detrimento de outra.

No que tange à definição dos direitos dessa natureza, conforme lição de Flávio Tartuce, estão eles ligados a cinco grandes ícones, quais sejam: A) Direito à vida e à integridade físico-psíquica; B) Proteção ao nome da pessoa; C) Imagem como atributo e proteção às características morfológicas da pessoa (imagem retrato); D) Honra (objetiva e subjetiva); E) Intimidade e vida privada. ${ }^{11}$ Ademais, temse como características serem inatos, indisponíveis, irrenunciáveis, analienáveis, imprescritíveis, absolutos, extrapatrimoniais e vitalícios. ${ }^{12}$

\section{DO ESTADO CIVIL DA PESSOA NATURAL}

O estado civil da pessoa corresponde ao conjunto de elementos que formam e individualizam concretamente a personalidade do indivíduo, a fim de precisar-

8 TARTUCE, Flávio. Manual de Direito Civil. 3. ed. São Paulo: Editora Método, 2013, p. 69-76.

9 AMARAL, Francisco. Direito Civil. Introdução. 5. ed. Rio de Janeiro: Editora Renovar, 2003, p. 249.

10 PELUSO, Cesar. Código Civil Comentado. 4. ed. São Paulo: Editora Manole, 2010, p. 15.

11 TARTUCE, Flávio. Manual de Direito Civil. 3. ed. São Paulo, Editora Método, 2013, p. 88.

12 VENOSA, Silvio de Salvo. Direito Civil. 11. ed. Vol. I. São Paulo: Editora Atlas, 2011, p. 171. 
Ihe o grau e a extensão dos seus direitos, deveres, capacidade civil, vínculos familiares, regimes jurídicos patrimoniais a que está submetido, e demais características formadoras e conformadoras da sua dignidade e personalidade, singularmente consideradas ${ }^{13}$.

Não é imutável, ao contrário, é dinâmico e obedece à posição jurídica da pessoa no seio da família, sociedade e estado. Corresponde a atributo da personalidade, genericamente compreendido como o direito à identidade. Seguindo o entendimento consentâneo, pode ser subdividido em quatro espécies ${ }^{14}$. A) Estado Político: identificação da naturalidade, nacionalidade e direitos políticos (capacidade eleitoral - ativa e passiva) da pessoa ${ }^{15}$; B) Estado Familiar: individualização da pessoa através da sua posição no âmbito familiar - solteiro, casado, separado, divorciado, vivendo sob o regime jurídico da união estável, viúvo e outro que eventualmente exista; C) Estado individual: identificação da pessoa por meio de características pessoais - sexo, gênero sexual, idade, capacidade de exercício (absolutamente incapaz, relativamente incapaz e plenamente capaz), saúde, grau de instrução, etc.; D) Estado Profissional: condição profissional da pessoa - Profissional liberal, Funcionário público, Militar, Advogado, Professor, Engenheiro, Sócio de Pessoa jurídica, Titular de EIRELI (Art. 980-A, CC), Empresário individual, etc.

O Estado civil da pessoa natural como elemento concreto de aferição dos atributos inerentes à personalidade de um dado indivíduo, conforme aponta a Professora Maria Helena Diniz, "é uno e indivisível, pois ninguém pode ser simultaneamente casado e solteiro, maior e menor, brasileiro e estrangeiro, salvo nos casos de dupla nacionalidade". ${ }^{16}$ Em igual sentido, no âmbito jurídico, ninguém pode ser tratado - ao mesmo tempo - como homem e mulher, a partir do critério binário de gênero admitido implicitamente pelo ordenamento pátrio (Art. $5^{\circ}$, inciso I, da CF).

Conforme já apontado, o estado civil da pessoa natural é dinâmico e visa acompanhar a posição jurídica real da pessoa no seio da sociedade. Alguns dos elementosintegrantes doestado civildapessoalhesãoincorporadosautomaticamente

13 VENOSA, Silvio de Salvo. Op. Cit., p. 160.

14 TARTUCE, Flávio. Manual de Direito Civil. 3. ed. São Paulo: Editora Método, 2013, p. 123.

15 CASSETTARI, Christiano (Coordenação). Registro Civil das Pessoas Naturais. Vol. I. São Paulo: Editora Saraiva, 2014, p. 37.

16 DINIZ, Maria Helena. Curso de Direito Civil Brasileiro. 24. ed. São Paulo: Editora Saraiva, 2007, p. 213. 
(a exemplo do sexo, da nacionalidade originária, da capacidade ou da incapacidade por critério etário, da própria profissão, etc.), outros dependem de ato jurídico formal ou fato jurídico para sua aquisição, modificação ou extinção (reconhecimento de capacidade eleitoral, aquisição do estado civil de casado, divorciado, etc.).

Ainda, determinados casos, mais restritos, exigem a intervenção judicial a fim de se verificar a aquisição ou modificação de elemento do estado civil da pessoa, a exemplo da ação de interdição por incapacidade, opção de nacionalidade, divórcio quando necessária a via judicial (Art. 733, Código de Processo Civil em vigência), ou a posse do estado civil, a exemplo do pseudônimo com que a pessoa é efetivamente conhecida e o gênero sexual que acredita pertencer, prova de posse do estado de casados (Art. 1.545, CC), separação de fato, e o próprio reconhecimento da posse do estado de filiação (filiação socioafetiva). ${ }^{17}$

Assim, a externalização concreta das características e os elementos que integram a personalidade do indivíduo constituem fundamento apto ao reconhecimento da modificação do Estado da pessoa humana.

Todos esses temas, tratados genericamente neste subtema, longe de esgotar o estudo, conjugam-se em premissas fundamentais à perfeita compreensão do objeto central.

\section{TRANSEXUALIDADE E REDESIGNAÇÃO DE GÊNERO}

Transexualidade, ou transexualismo, corresponde à contradição entre o sexo biológico e anatômico do ser humano singularmente considerado, e o gênero sexual no qual ele acredita e externaliza pertencer, material e psicologicamente, resultando na rejeição às características morfológicas do próprio corpo ${ }^{18}{ }^{19}$. O vocábulo 'transexual', que somente veio a receber esta denominação no início do 17 ROSENVALD, Nelson; FARIAS, Cristiano Chaves de. Curso de Direito Civil. Vol. 1. 13. ed. São Paulo: Editora Atlas, 2015, p. 304.

18 GONÇALVES, Camila de Jesus Mello. A transexualidade sob a ótica dos direitos humanos: uma perspectiva de inclusão. Tese de Doutorado apresentada perante a Faculdade de Direito da Universidade de São Paulo - USP, ano de 2012, p. 55-56. Tese integral disponível através do portal: http://www.teses.usp.br/teses/disponiveis/2/2140/tde-04032013105438/pt-br.php, acessado em: 20/09/2016.

19 DINIZ, Maria Helena. Dicionário Jurídico. Vol. IV. São Paulo: Editora Saraiva, 2008, p. 608. 
Século XX, começa a ser identificado e descrito pela literatura médica a partir do Século XIX, em que pese sempre tenha existido. ${ }^{20}$

Ademais, de acordo com a Organização Mundial de Saúde, a transexualidade é classificada como uma patologia enquadrada como distúrbio psíquico, na Classificação Estatística Internacional de Doenças e Problemas Relacionados com a Saúde - CID-10, sob código F640. Essa classificação como distúrbio psíquico tem recebido severas críticas, ao passo que alguns países, inclusive, afastaram a sua identificação como patologia, a exemplo da França, que retirou - no ano de 2010 - a transexualidade do seu catálogo nacional de doenças. ${ }^{21}$

Há, ainda, uma importante distinção classificatória da transexualidade, em primária e secundária. A primária corresponde à convicção precoce, impulsiva e permanente do indivíduo em pertencer ao sexo oposto àquele externalizado pelas suas características morfológicas. A transexualidade secundária, por sua vez, não é dotada - como regra - dessas características de precocidade, impulsividade e permanência, mas sim caracterizando-se pela vontade consciente, transitória e intermitente do indivíduo de possuir o sexo oposto, substancialmente ligada ao exercício da atividade sexual. ${ }^{22}$

Ademais, importante ressaltar, a transexualidade está ligada à identidade sexual do indivíduo ${ }^{23}$, pois seja, ao gênero sexual (masculino ou feminino) que acredita e demonstra permanentemente pertencer, e não à orientação sexual, que corresponde ao sentimento, interesse, atração afetiva e sexual por pessoas do sexo biológico oposto (heterossexualidade), do mesmo (homossexualidade), 20 SAADEH, Alexandre. Boletim ICAPS, junho de 2005, no 231, p. 8. Disponível através do site: http://www.icaps.org.br/wp-content/uploads/2015/12/Icaps-231.pdf, acessado em 28/09/2016.

21 GONÇALVES, Camila de Jesus Mello. A transexualidade sob a ótica dos direitos humanos: uma perspectiva de inclusão. Tese de Doutorado apresentada perante a Faculdade de Direito da Universidade de São Paulo - USP, ano de 2012, p. 53. Tese integral disponível através do portal: http://www.teses.usp.br/teses/disponiveis/2/2140/tde-04032013105438/pt-br.php, acessado em: 20/09/2016.

22 KLABIN, Aracy Augusta Leme. Aspectos jurídicos do Transexualismo. Artigo Publicado na Revista da Faculdade de Direito da Universidade de São Paulo, V. 90, ano de 1995, p. 197.

23 JESUS, Jaqueline Gomes de. Orientações sobre a população transgênero: Conceitos e termos. Artigo publicado, ano de 2012, p. 7. Núcleo de Estudos e Pesquisas em gênero e Sexualidade da Universidade Federal de Goiás. Disponível através do site: https:// www.sertao.ufg.br/up/16/o/ORIENTA\%C3\%87\%C3\%95ES_POPULA\%C3\%87\%C3\%830_ TRANS.pdf?1334065989, acessado em 28/09/2016. 
de ambos (bissexualidade), de qualquer sexo (pansexualidade) ou de nenhum deles (assexualidade) ${ }^{24}$. Isso significa dizer que não necessariamente 0 transexual tenha orientação sexual que corresponda à atração pelo sexo biológico equivalente ao seu, originariamente. Pois seja, o transexual não é necessariamente biologicamente homossexual. ${ }^{25}$

A figura do gênero sexual, por sua vez, muito mais do que representar a distinção de pessoas através de um critério biológico puro (nascer homem ou mulher), corresponde a um elemento de identificação e distinção das pessoas - homens e mulheres - através de características e padrões individuais e sociais externalizadas, que o são próprias de cada gênero, por um critério tradicionalmente binário (masculino e feminino), e repercutem no âmbito das relações interpessoais e jurídicas entre os indivíduos. A distinção de gênero (e a repercussão que dela emana) é fruto de uma construção histórica profunda, dinâmica e - atualmente em acelerada mutação. ${ }^{26}$

Em verdade, aos dias atuais, à luz de fatos históricos inéditos e característicos deste início do Século XXI, marcado pela quebra de importantes paradigmas sociais, tem-se colocado em xeque a própria natureza binária do gênero humano, reconhecendo-se a existência do que se concebeu designar de terceiro gênero, ou gênero neutro. $O$ terceiro gênero comporta os indivíduos não identificados nem com o gênero masculino, nem com o feminino, seja por exercitarem as características de ambos os gêneros, mutuamente, identificando-se como intersexuais (gênero neutro), seja por se identificarem como integrantes de um gênero próprio, característico da sua condição física e psicossocial.

Nesse sentido, foram os Estudos feitos por Rainner Jerônimo Roweder, em Tese de Mestrado apresentada no ano de 2015 perante a Universidade Federal de Minas Gerais, que recebeu o título de 'O TERCEIRO GÊNERO: POLÍTICAS PÚBLICAS

24 VEIGA, Ana Paula. Assexualidade. Artigo 752. Disponível no site: https://www.abcdasaude.com.br/sexologia/assexualidade. Acessado na data de 06/10/2016.

25 GONÇALVES, Camila de Jesus Mello. A transexualidade sob a ótica dos direitos humanos: uma perspectiva de inclusão. Tese de Doutorado apresentada perante a Faculdade de Direito da Universidade de São Paulo - USP, ano de 2012, p. 64. Tese integral disponível através do portal: http://www.teses.usp.br/teses/disponiveis/2/2140/tde-04032013105438/pt-br.php, acessado em: 20/09/2016.

26 FACHIN, Luiz Edson. Revista Brasileira de Direito Civil. Vol. 1, Julho/2014, p. 50. 


\section{E MECANISMOS JURÍDICOS DE VALORIZAÇÃO DA DIGNIDADE HUMANA PELO} VIÉS DO GÊNERO. Nesse trabalho, foi apontado que alguns países, a exemplo da Alemanha, Austrália e Índia, atualmente, já reconhecem juridicamente a existência de um terceiro gênero sexual. ${ }^{27}$

No ano de 1992, reconheceu-se o direito de um brasileiro, que teve cirurgia de redesignação de sexo realizada na Suiça, a alteração do seu Assento de nascimento constante do Registro Civil das Pessoas Naturais (RCPN), para constar a mudança de sexo. Contudo, o Magistrado, na época, decidiu - através de Sentença transitada em julgado - devesse ser averbada a mudança de sexo para constar que o Registrado passou à condição de 'transexual', reconhecendo-o como um gênero sexual próprio. ${ }^{28}$

Atualmente, este tema teve o reconhecimento de Repercussão Geral no âmbito do Supremo Tribunal Federal, o qual ainda não o fora julgado definitivamente. In verbis

EMENTA DIREITO CONSTITUCIONAL E CIVIL. REGISTROS PÚBLICOS. REGISTRO CIVIL DAS PESSOAS NATURAIS. ALTERAÇÃO DO ASSENTO DE NASCIMENTO. RETIFICAÇÃO DO NOME E DO GÊNERO SEXUAL. UTILIZAÇÃO DO TERMO TRANSEXUAL NO REGISTRO CIVIL. O CONTEÚDO JURÍDICO DO DIREITO À AUTODETERMINAÇÃO SEXUAL. DISCUSSÃO ACERCA DOS PRINCÍPIOS DA PERSONALIDADE, DIGNIDADE DA PESSOA HUMANA, INTIMIDADE, SAÚDE, ENTRE OUTROS, E A SUA CONVIVÊNCIA COM PRINCÍPIOS DA PUBLICIDADE E DA VERACIDADE DOS REGISTROS PÚBLICOS. PRESENÇA DE REPERCUSSÃO GERAL. (RE 670422 RG, Relator(a): Min. DIAS TOFFOL, julgado em 11/09/2014, ACÓRDÃO ELETRÔNICO DJe229 DIVULG 20-11-2014 PUBLIC 21-11-2014 )

Entrementes, independentemente de traçar qualquer juízo valorativo acerca da pertinência ou não do reconhecimento de um terceiro gênero, fato é que o ordenamento jurídico brasileiro está alicerçado no tradicional critério binário.

27 ROWEDER, RAINNER JERÔNIMO. O terceiro gênero: Políticas públicas e mecanismos jurídicos de valorização da dignidade humana pelo viés do gênero. Dissertação de Mestrado apresentada perante o Programa de Pós-Graduação da Faculdade de Direito da Universidade Federal de Minas Gerais - UFMG, 2015, p. 58; 60-61; 63. Disponível através do portal: http://www.bibliotecadigital.ufmg.br/dspace/handle/1843/BUBD-A3WFAK, acessado em 01/11/2016.

28 RIBEIRO, Benedito Silvério. Análise dos Casos que Implicam Alterações no Registro Civil. In Serviços Notariais e de Registro. $1^{\circ}$ Simpósio Nacional de Serviços Notariais e Registrais de São Paulo, 09/1996, p. 142. 
E seguindo esse critério (homem e mulher), cumulado com a compreensão da primazia da identidade do gênero em face da biológica pura, denomina-se mulher transexual aquela que tenha nascido com o fenótipo masculino e acredite - psicologicamente - pertencer ao sexo oposto, e homem transexual aquele que tenha nascido com o fenótipo feminino, e acredite e se manifeste perante a sociedade como integrante do gênero masculino.

À luz desse quadro, tendo em conta o fato de essa inadequação entre o sexo biológico e a identidade de gênero do indivíduo (exteriorização psicossocial ${ }^{29}$ do sexo), psicologicamente e externalizada perante a sociedade, gerar o sentimento de ter nascido num corpo que não é seu, resultante em severas consequências e riscos à vida e à higidez física e psíquica, tornou impositiva - em respeito à dignidade da pessoa humana - e sem descurar dos valores da fraternidade, não discriminação, e busca pela felicidade existencial, a implementação de medidas capazes de tutelar adequadamente essas pessoas, atenuando ou quiçá lhes interrompendo o sofrimento e permitindo que o tenham uma vida livre e socialmente integrada.

Nesse diapasão, a partir de uma ponderação de valores e princípios constitucionais fundamentais, todos de elevado patamar, como o da proteção à vida e integridade físico-psíquica do ser humano, direito ao próprio corpo, indisponibilidade relativa do próprio corpo, da preservação da sua autonomia decisória e liberdade existencial, vida privada, intimidade e a própria busca pela felicidade, este último atualmente considerado como valor constitucional implícito ${ }^{30}$, aliados à evolução da Medicina, legitimou-se a formação de normas, orientações, procedimentos e precedentes jurisprudenciais que caminham no sentido de reconhecer às pessoas diagnosticadas ou reconhecidas como transexuais o direito de ter realizadas as medidas necessárias à redesignação do sexo, e alterado o(s) assento(s) do registro civil respectivo (nascimento e/ou casamento), para que passe a constar a averbação da mudança de sexo, e da mudança do prenome.

29 JESUS, Jaqueline Gomes de. Orientações sobre a população transgênero: Conceitos e termos. Artigo publicado, ano de 2012. Núcleo de Estudos e Pesquisas em gênero e Sexualidade da Universidade Federal de Goiás. Disponível através do site: https://www.sertao.ufg.br/ up/16/o/ORIENTA\%C3\%87\%C3\%95ES_POPULA\%C3\%87\%C3\%830_TRANS. pdf?1334065989, acessado em 28/09/2016.

30 SUPREMO TRIBUNAL FEDERAL. RE 477.554 AgR, rel. min. Celso de Mello, j. 16-8-2011, 2a T, DJE de 26-8-2011. Disponível em: http://www.stf.jus.br/portal/constituicao/artigobd. asp?item=4, acessado em 05/10/2016. 
A redesignação sexual, popularmente conhecida como mudança de sexo, no âmbito físico do indivíduo, compreende uma gama de intervenções e tratamentos de natureza cirúrgica, clínica, psiquiátrica, psicológica, endócrina e assistencial, destinadas a uma readequação das características físicas e psíquicas decorrentes do sexo biológico, postos à disposição das pessoas que se enquadram na condição de transexuais primários (vide Resolução n 1.955/2010, do Conselho Federal de Medicina, e Portaria n².803/2013, do Ministério da Saúde).

A cirurgia de transgenitalização, que compreende a intervenção destinada à extração da genitália externa e criação de uma genitália interna (neocolpovulvoplastia) e implante de prótese mamária de silicone, para as mulheres transexuais (biologicamente pertencentes ao sexo masculino), e o fechamento da genitália interna, retirada das mamas (mastectomia), do útero e ovários (histerectomia), implante peniano ${ }^{31}$ (através da cirurgia de faloplastia ou neofaloplastia) ou descolamento do clitóris (Metoidioplastia) e implante de testículos (escrotoplastia) ${ }^{32}$, para os homens transexuais (biologicamente pertencentes ao sexo feminino), tal como cirurgias plásticas e o tratamento hormonal destinado à adaptação ao fenótipo pretendido, por gerarem efeitos drásticos e irreversíveis, exigem uma criteriosa avaliação e acompanhamento, a fim de se aferir a real necessidade do tratamento, devidamente orientada quanto aos seus efeitos, e evitar que as pessoas venham a se arrepender da medida no futuro, só é reconhecida aos transexuais classificados como primários, porquanto os transexuais secundários, também denominados de falsos transexuais ou transexuais homossexuais, não manifestam interesse permanente em possuir características do sexo oposto.

Até o ano de 1997, era vedada por orientação do Conselho Federal de Medicina, sendo inicialmente autorizada pela Resolução n 1.482, de 10/09/1997. Aos dias atuais, as intervenções destinadas à redesignação sexual estão reguladas através da Resolução n 1.955, datada de 12/08/2010, do Conselho Federal de Medicina, 31 BRASIL, Ministério da Saúde. Portaria no 2.803, de 19/11/2013. Disponível pelo site: http://bvsms.saude.gov.br/bvs/saudelegis/gm/2013/prt2803_19_11_2013.html, acessado em 17/10/2016.

32 Hospital Kamol. Banguecoque, Tailândia. Especializado em técnica de transsexualização. Disponível pelo site: http://www.kamolhospital.com/pt/FTM-surgery/ reconstru\%C3\%A7\%C3\%A3o-genital, acessado em 16/10/2016. 
e Portaria n 2.803, datada de 19/11/2013, do Ministério da Saúde. O processo tendente à redesignação de sexo é feito por etapas, após um acompanhamento cuja duração mínima é de 24 (vinte e quatro) meses, conforme preconiza o Art. $3^{\circ}$, da citada normatização do Conselho Federal de Medicina. A idade mínima para requerer a iniciação do Processo de transexualização é de 18 (dezoito) anos de idade, momento em que o requerente passará a ser submetido a contínuos exames e avaliações, podendo iniciar desde então o tratamento de hormonioterapia, contudo, os procedimentos cirúrgicos somente poderão ser realizados após atingir 21 (vinte e um) anos (vide Art. 14, § $2^{\circ}$, da Portaria $n^{\circ}$ 2.803/2013, do Ministério da Saúde).

Esse conjunto de métodos destinados à redesignação de sexo encontra clara guarida nos direitos da personalidade, seja por estarem respaldados em conclusões da medicina psiquiátrica, que evidenciam a necessidade do tratamento como instrumento de proteção do direito à vida dos transexuais, que muitas das vezes manifestam sentimento suicida ou de automutilação, com fulcro à interpretação literal do Art. 1333, do Código Civil, seja em respeito aos demais direitos inerentes à dignidade e à personalidade da pessoa, como o da identidade sexual, corolário da autonomia privada, direito ao próprio corpo, proteção à honra, imagem, autoestima, busca pela felicidade, além do respeito à diversidade e não discriminação. ${ }^{34}$

Ademais, a redesignação sexual através de cirurgia deve ser vista - sempre - sob a perspectiva de um direito posto à disposição do transexual, mas nunca sob o prisma de um dever ou requisito imperativo necessário à tutela dos seus direitos.

\section{DO DIREITO À ALTERAÇÃO DO REGISTRO CIVIL DA PESSOA}

NATURAL

Atualmente, nossos Tribunais ${ }^{35}$, partindo de uma intelecção sistêmica de todo o ordenamento jurídico, à luz dos fins sociais a que as normas se destinam e da tutela

33 SCHREIBER, Anderson. Direitos da Personalidade. 2. ed. São Paulo: Atlas, 2013, p. 44.

34 FACHIN, Luiz Edson. Revista Brasileira de Direito Civil. Vol. 1, Julho/2014, p. 47;49.

35 BRASIL. SUPERIOR TRIBUNAL DE JUSTIÇA. REsp 737.993/MG, Rel. Ministro JOÃO OTÁVIO DE NORONHA, QUARTA TURMA, julgado em 10/11/2009, DJe 18/12/2009; e (REsp 1008398/SP, Rel. Ministra NANCY ANDRIGHI, TERCEIRA TURMA, julgado em 15/10/2009, DJe 18/11/2009). Disponível através do portal: http://www.stj.jus.br, acessado em 06/11/2016. 
material e formal da dignidade da pessoa humana, têm reconhecido o direito de transexuais à alteração do Assento (nascimento e - eventualmente - casamento) constante do Ofício do Registro Civil da Pessoa Natural (RCPN), para substituir o sexo biológico da pessoa pelo gênero compatível com sua identidade sexual, tal como alterar o prenome por outro 'vocábulo de identificação'36 compatível com a identidade de gênero sexual, abandonando completamente aquele que constara originariamente do seu assento de nascimento e - eventualmente - até do de casamento.

Ao nascer, como regra, tem-se a definição do sexo biológico da pessoa (homem ou mulher). A exceção é o hermafroditismo ${ }^{37}$, decorrente da má-formação fetal, com ou sem predominância ulterior de um dos sexos. O sexo biológico é o que deve, por força do Art. 54, item $2^{\circ}$, da LRP (Lei 6.015/1973), obrigatoriamente constar do Assento de Nascimento da Pessoa.

Está inserido no âmbito do estado individual da pessoa, e a sua mudança exige Sentença judicial que reconheça a posse pública, contínua e definitiva dessa condição inerente ao estado, como forma de aquisição formal, no caso do nome, ou modificação, no caso do sexo, neste último caso tutelando a prevalência da identidade de gênero em face da biológica pura.

Tais alterações estão sujeitas à averbação à margem do assento de nascimento da pessoa natural (vide, inclusive, o Art. 29, $\S 1^{\circ}$, alínea $f, L R P$ ), que poderá igualmente ser objeto de averbação no casamento vigente que porventura tenha, ou anotação no(s) Assento(s) de casamento anterior(es) já dissolvido(s), havendo controvérsia, nessas últimas hipóteses, se a própria alteração do gênero sexual e nome constante do Registro Civil, dependeria de anuência prévia do cônjuge do transexual ou daqueles que já o tenham sido para fins de fazer constar esse fato no Assento e Certidão de casamento respectiva ${ }^{38}$.

36 PEREIRA, Rodrigo da Cunha (Org). Tratado de Direito das Famílias. 1. ed. Belo Horizonte: Instituto Brasileiro de Direito de Família - IBDFAM, 2015, p. 451.

37 CASSETTARI, Christiano (Coordenação). Registro Civil das Pessoas Naturais. Vol. I. São Paulo: Editora Saraiva, 2014, p 252.

38 GONÇALVES, Camila de Jesus Mello. A transexualidade sob a ótica dos direitos humanos: uma perspectiva de inclusão. Tese de Doutorado apresentada perante a Faculdade de Direito da Universidade de São Paulo - USP, ano de 2012, p. 235-239. Tese integral disponível através do portal: http://www.teses.usp.br/teses/disponiveis/2/2140/tde-04032013105438/pt-br.php, acessado em: 20/09/2016. 
Aos dias atuais, tem-se reconhecido que a Cirurgia de transgenitalização e demais intervenções destinadas à redesignação sexual não o são requisitos sine qua non ao deferimento da alteração do nome e sexo no Assento constante do Registro Civil da Pessoa natural reconhecida como transexual ${ }^{39}$. Nesse sentido, caminha a orientação Jurisprudencial mais recente dos Tribunais de Justiça dos Estados, com amparo em respeitosa doutrina..$^{40} 42$ In verbis:

APELAÇÃO CÍVEL. RETIFICAÇÃO DO REGISTRO CIVIL. TRANSEXUALISMO. ALTERAÇÃO DO GÊNERO. AUSÊNCIA DE CIRURGIA DE REDESIGNAÇÃO SEXUAL OU TRANSGENITALIZAÇÃO. POSSIBILIDADE. O sexo é físicobiológico, caracterizado pela presença de aparelho genital e outras características que diferenciam os seres humanos entre machos e fêmeas, além da presença do código genético que, igualmente, determina a constituição do sexo - cromossomas XX e XY. O gênero, por sua vez, refere-se ao aspecto psicossocial, ou seja, como o indivíduo se sente e se comporta frente aos padrões estabelecidos como femininos e masculinos a partir do substrato físico-biológico. É um modo de organização de modelos que são transmitidos tendo em vista as estruturas sociais e as relações que se estabelecem entre os sexos. Considerando que o gênero prepondera sobre o sexo, identificando-se o indivíduo transexual com o gênero oposto ao seu sexo biológico e cromossômico, impõe-se a retificação do registro civil, independentemente da realização de cirurgia de redesignação sexual ou transgenitalização, porquanto deve espelhar a forma como o indivíduo se vê, se comporta e é visto socialmente. Sentença de procedência confirmada. POR MAIORIA, COM TRÊS VOTOS A DOIS, NEGARAM PROVIMENTO AO RECURSO, VENCIDOS O RELATOR E A DESA. LISELENA SCHIFINO ROBLES RIBEIRO. (Apelação Cível No 70070185566, Sétima Câmara Cível, Tribunal de Justiça do RS, Relator: Sérgio Fernando de Vasconcellos Chaves, Julgado em 26/10/2016)

Tais orientações, contudo, ainda não são unânimes, tampouco encontram consolidado respaldo nos Tribunais Superiores. No âmbito do Superior Tribunal de

39 FACHIN, Luiz Edson. Revista Brasileira de Direito Civil. Vol. 1, Julho/2014, p. 59-63.

40 BRASIL. Tribunal de Justiça do Estado do Rio Grande do Sul. Apelação Cível No 70071176762, Sétima Câmara Cível, Tribunal de Justiça do RS, Relator: Liselena Schifino Robles Ribeiro, Julgado em 26/10/2016. Disponível através do portal: http://www.tjrs.jus. br, acessado em 30/10/2016.

41 BRASIL. Tribunal de Justiça do Estado de São Paulo. Relator(a): J.B. Paula Lima; Comarca: São Paulo; Órgão julgador: 10a Câmara de Direito Privado; Data do julgamento: 20/09/2016; Data de registro: 21/09/2016. Disponível através do portal: http://www.tjsp. jus.br, acessado em 30/10/2016.

42 BRASIL. Tribunal de Justiça do Estado de São Paulo. Relator(a): Claudio Godoy; Comarca: São Paulo; Órgão julgador: $1^{a}$ Câmara de Direito Privado; Data do julgamento: 08/07/2016; Data de registro: 08/07/2016. Disponível através do portal: http://www.tjsp. jus.br, acessado em 30/10/2016. 
Justiça, até o encerramento deste artigo, vislumbra-se orientação Jurisprudencial ainda não consonante ao entendimento mais recente, somente reconhecendo o direito à alteração do Registro Civil da pessoa natural quando submetida ao processo médico de transexualização, com submissão da pessoa à cirurgia de transgenitalização e demais tratamentos.

Nesse contexto, há a tramitação, no âmbito Supremo Tribunal Federal, da ADIN n 4.275, proposta pela Procuradoria Geral da República, que busca atribuir interpretação conformea Constituição ao Art. 58, Parágrafoúnico, da Lei6.015/1973, para o fim de reconhecer aos transexuais o direito à mudança de prenome e sexo no Assento constante do Registro Civil respectivo, independentemente de cirurgia de transgenitalização. Encontra-se pendente de julgamento.

\section{NATUREZA JURÍDICA E EFEITOS DA DECISÃO JUDICIAL}

O estado civil da pessoa, como atributo inerente à personalidade, no caso específico da identidade de gênero sexual diverso do sexo biológico, tal como o nome social com o qual o transexual é efetivamente conhecido, tem como primeiro requisito necessário ao seu reconhecimento a exteriorização (publicidade) contínua (permanência) e definitiva dessa condição, denominada posse de estado. Essa exteriorização, em que pese inapta a operar eficácia erga omnes como não reconhecida por sentença e averbada no Ofício do RCPN, repercute no âmbito individual da pessoa - que tem essa posse de estado incorporada à sua personalidade, desde o instante que se consolidar como tal, a exemplo da tutela ao pseudômino (Art. 19, CC), cuja proteção material não é adstrita à prévia averbação deste elemento de identificação no Registro Civil.

Uma vez verificada a posse de estado civil individual decorrente da identidade de gênero diversa do sexo biológico constante do RCPN, surge ao indivíduo o direito subjetivo de buscar, na via Jurisdicional, através de Ação submetida ao procedimento geral de jurisdição voluntária (Art. 719, e seguintes, do Código de Processo Civil em vigência), o reconhecimento desse direito, a fim de ter o seu Assento constante do Registro Civil de nascimento alterado para constar a mudança de nome e/ou sexo. 
A sentença, nesse caso, possui natureza constitutiva ${ }^{43}$ do novo estado individual da pessoa, formalmente. Assim, como regra, os efeitos da decisão que institui formalmente o novo estado da pessoa operam ex nunc, pois seja, irretroativamente.

Em relação aos efeitos temporais da averbação da mudança, a melhor solução é aquela que preserva válidos os efeitos do registro até a data do reconhecimento da identidade de gênero, mantendo uma perfeita paridade temporal entre a informação do registro e a identidade da pessoa.

A irretroatividade da mudança consta expressamente nas leis italiana, inglesa, espanhola, belga e portuguesa, reconhecendo-se a pessoa tanto sob o gênero natural quanto pela identidade sexual, a depender de como estava a inscrição do registro na data do fato. Assim, permanecem intactos os atos praticados até a data da mudança, admitindo-se a pessoa como pertencente ao outro sexo a partir da data da averbação da identidade sexual, como efeitos para o futuro (art. $4^{\circ}$, da Lei Italiana 164/1982; art. 9.2, do Recogniton Gender Act do Reino Unido; art. 50, da Lei Espanhola n 3/2007; art. $2^{\circ}$, § 4 , da Lei Belga $n^{\circ} 10 / 55$, de 2007, e art. $5^{\circ}$, da Lei Portuguesa 7/2011). ${ }^{44}$

Assim, em respeito ao primado da segurança jurídica, e das regras que the são decorrentes, a alteração do estado civil do transexual para harmonizá-lo à identidade de gênero da pessoa não prejudica os atos jurídicos formados e concluídos antes de constituída a sua modificação, através de Sentença Judicial, que somente após averbação no Ofício do RCPN respectivo gerará eficácia erga omnes. ${ }^{45}$

Com efeito, em que pese a alteração dos elementos da personalidade do indivíduo - genericamente - não dependam necessariamente de um Sentença judicial que reconheça esta condição, no caso específico da alteração do sexo de pessoa transexual, em respeito à segurança jurídica e à regra da unitariedade e indivisibilidade dos elementos de estado, faz-se imperiosa a alteração formal do estado da pessoa, através de Sentença constitutiva averbada no RCPN.

43 DIDIER JR., Fredie. Curso de Direito Processual Civil. 10. ed. Vol 1. Salvador/BA: Editora JusPodivm, 2008, p. 196.

44 GONÇALVES, Camila de Jesus Mello. A transexualidade sob a ótica dos direitos humanos: uma perspectiva de inclusão. Tese de Doutorado apresentada perante a Faculdade de Direito da Universidade de São Paulo - USP, ano de 2012, p. 223. Tese integral disponível através do portal: http://www.teses.usp.br/teses/disponiveis/2/2140/tde-04032013105438/pt-br.php, acessado em: 20/09/2016.

45 CASSETTARI, Christiano (Coordenação). Registro Civil das Pessoas Naturais. Vol. I. São Paulo: Editora Saraiva, 2014, p. 49-52. 


\section{A DISTINÇÃO DE GÊNERO COMO CRITÉRIO DE DISCRIMINAÇÃO PARA FINS PREVIDENCIÁRIOS}

\section{PANORAMA DA ESTRUTURA NORMATIVA PREVIDENCIÁRIA - CONSTITUCIONAL E INFRACONSTITUCIONAL}

O direito à Previdência Social, juntamente com o direito à Saúde e Assistência Social, está inserido dentre os direitos fundamentais atinentes à ordem social (vide art. $6^{\circ}, \mathrm{CF}$ ) e compreendida como elemento integrante da Seguridade Social (Art. 194, CF). Tem por objeto assegurar "aos seus beneficiários meios indispensáveis de manutenção, por motivo de incapacidade, idade avançada, tempo de serviço, desemprego involuntário, encargos de família e reclusão ou morte daqueles de quem dependiam economicamente" (Art. $3^{\circ}$ da Lei 8.212/1991).

Está a Previdência Social subdividida em Regimes básicos, de vinculação obrigatória, compreendido o Regime Geral da Previdência Social - RGPS (Lei 8.213/1991), e Regimes próprios dos Servidores públicos Federais (Lei 8.112/1991), do Distrito Federal, Estaduais e Municipais, no âmbito da Administração pública direta e indireta, Congressistas Federais (vinculação facultativa - Lei 9.507/1997) e Militares (Federais - Lei 6.880/1980, e Estaduais), desde que regulados por lei específica, e os Regimes de previdência complementar, de vinculação facultativa (regulado pela Lei Complementar 109/2001), de natureza pública ou privada, este último subdividido em aberto ou fechado ${ }^{46}$.

Dentre o rol de benefícios instituídos pelo Regime Geral da Previdência Social, alguns deles traçam - dentre os requisitos e pressupostos necessários à concessão - critério e tratamento diferenciado pautado na distinção de gênero entre homens e mulheres, que, ressalte-se, é seguido pelos outros Regimes próprios de Previdência. Exemplificando:

A) no âmbito do benefício de Aposentadoria por idade, homens se aposentam com 65 (sessenta e cinco) anos, e mulheres com 60 (sessenta) anos, com redução 46 GOES, Hugo. Manual de Direito Previdenciário - Teoria e questões.10. ed. Rio de Janeiro: Editora Ferreira, 2015, p. 15-16. 
de 5 (cinco) anos, em ambos os sexos, quando exercentes de atividade rural nas condições que a lei explicita (vide art. 201, § $7^{\circ}$, II, CF, e Art. 48 e seguintes, da Lei 8.213/1991). Ademais, o período de carência é de 180 (cento e oitenta) contribuições mensais, para ambos os sexos (Art. 25, II, da Lei 8.213/1991);

B) partindo da mesma lógica, na modalidade de Aposentadoria por tempo de contribuição, exige-se aos homens o equivalente a 35 (trinta e cinco) anos de contribuição, e às mulheres o equivalente a 30 (trinta) anos (vide art. 201, $\S 7^{\circ}, \mathrm{I}$, e $\S 8^{\circ}, \mathrm{CF}$ ), observado o mesmo período de carência de 180 (cento e oitenta) contribuições mensais, os quais terão o prazo reduzido em 5 (cinco) anos, em ambos os casos, para o segurado que comprove exclusivamente tempo de efetivo exercício das funções de magistério na educação infantil e no ensino fundamental e médio;

O princípio da igualdade material é o fundamento que legitimou a instituição de um tratamento discriminatório que contempla períodos aquisitivos distintos - tomando como base um critério binário de gênero - entre homens e mulheres, para fins de concessão de aposentadoria.

Segundo este princípio, a igualdade se assenta em tratar igualmente aqueles que se encontram na mesma posição, real e concretamente, e desigualmente aqueles que se encontram em posição de desigualdade, na proporção razoável e adequada - positiva ou negativa - das suas respectivas desigualdades. O critério discriminatório pautado na isonomia material deve estar amparado em correlação lógica com a causa que o justifique, e cujo tratamento fruto dessa correlação exige-se seja apto a atingir um fim legítimo de equiparação material, admitido pelos valores constitucionais. ${ }^{47}$

Duas são - essencialmente - as causas que legitimam, em tese, a instituição de tratamento jurídico diferenciado entre os gêneros nessas hipóteses suso elencadas, com exceção do benefício do salário maternidade, cujo fundamento é lógico, e visa tutelar à gestante (ou pessoa que a faça as vezes) e ao recém-nascido.

A primeira causa decorre da vulnerabilidade da mulher no mercado de trabalho, que possui uma maior taxa de desocupação em comparação aos homens, em 47 MELLO, Celso Antônio Bandeira de. 0 conteúdo jurídico do princípio da igualdade. 3. ed. 24a Tiragem. São Paulo: Malheiros editores, 2015. 
função do número de oportunidades profissionais que privilegiam - ainda hoje - o sexo masculino, tal como a desigualdade de tratamento profissional e remuneratório entre os gêneros. Tem por objetivo influenciar - positivamente o processo de inserção da mulher no mercado de trabalho. ${ }^{48}$ Outros sustentam que a fragilidade física da mulher como fundamento que legitima o critério e o tratamento discriminatório.

A segunda causa, pautada numa realidade histórico-cultural, sustenta-se na premissa de que a mulher exerce - além da rotina profissional - atividades domésticas não remuneradas.

Importante ressaltar, esse critério de tratamento discriminatório, teoricamente fundado na isonomia material, remonta à Lei n 3.807/1960 - Lei Orgânica da Previdência Social, que instituiu as modalidades de Aposentadoria por velhice (hoje equivalente à aposentadoria por idade) e por tempo de serviço (hoje equivalente à aposentadoria por tempo de contribuição), com uma diferença de 5 (cinco) anos de idade ou serviço, entre homens e mulheres, para fins de perfectibilização da idade ou tempo mínimo para concessão do respectivo benefício.

O contexto social contemporâneo, já passados mais de 55 (cinquenta e cinco) anos desde a implementação dessa modalidade de ação afirmativa, é muito diverso daquele existente à época, o que resulta na inadequação desse critério de tratamento discriminatório como instrumento de satisfação da justiça social, acarretando distorções e injustiças concretas.

\section{O DIREITO À APOSENTADORIA DAS PESSOAS TRANSEXUAIS}

Diante do caráter recente da mudança de orientação Jurisprudencial, que passou a admitir a averbação da alteração do sexo e nome no Assento de nascimento da pessoa transexual, constante do RCPN, em decorrência do reconhecimento da identidade de gênero, ainda não se vislumbra - no âmbito nacional - a existência de 48 IPEA - Instituto de Pesquisa econômica aplicada. Mulheres e trabalho: breve análise do período 2004-2014. Nota técnica n² 24. Brasília, 03/2016. Disponível através do portal: http://www.ipea.gov.br/portal/index.php?option=com_content\&view=article\&id=27317, acessado em: 08/11/2016. 
precedentes jurisprudenciais ou orientações administrativas editadas pelo INSS, em relação à forma de tratamento a ser dada no caso de aposentadoria de pessoa que alterara o seu Registro civil em decorrência de mudança de sexo, razão pela qual, as ponderações e as possíveis soluções trazidas com este Artigo, longe de encerrar ou esvaziar discussão acerca do tema, têm por escopo abrir a perspectiva de debate.

Primeiramente, fulcral considerar, em respeito à eficácia constitutiva da alteração formal do estado da pessoa que mudou de sexo, acredita-se não possa o transexual pretender receber tratamento previdenciário diverso daquele que decorre do seu Estado Civil formalmente constituído, enquanto não efetivada formalmente dita alteração. Pois seja, enquanto não reconhecido - no âmbito Jurisdicional - a existência de identidade de gênero diversa da biológica, e efetivada a alteração do sexo da pessoa no Assento constante do RCPN, não há se cogitar a pretensão de tratamento previdenciário diferenciado.

Assim, a alteração formal do Estado civil da pessoa, com averbação no RCPN respectivo, é requisito essencial à pretensão de se receber tratamento jurídico previdenciário de acordo com o novo gênero sexual. $E$, uma vez procedida à alteração, esta não tem sua repercussão adstrita a uma espécie específica de relação jurídica, mas sim interfere em toda e qualquer espécie de relação a que a pessoa possa estar sujeita em função da distinção de gênero.

Um caso emblemático, nessa linha de intelecção, fora julgado no ano de 2014 pelo Tribunal Regional Federal da $1^{a}$ Região, envolvendo uma mulher transexual (sexo biológico masculino), Militar da Aeronáutica, que havia sido Reformada e afastada do exercício das suas atividades em função da realização de cirurgia de transgenitalização e alteração do registro civil respectivo, porquanto não havia quadro a ser integrado por mulher no Posto até então ocupado pela militar, enquanto homem, reconhecendo o órgão Jurisdicional, na ocasião, o dever de a Administração Militar conferir tratamento adequado à nova condição sexual da autora, permitindo o exercício das suas atividades em igualdade de condições, e fazendo jus a toda espécie de promoções que teria direito. Declarou-se a nulidade do ato administrativo que importou no seu desligamento das Forças Armadas, com efeito ex tunc. ${ }^{49}$

49 BRASIL. TRIBUNAL REGIONAL FEDERAL DA $1^{\text {a }}$ REGIÃO - TRF-1. AC 002548296.2002.4.01.3400 / DF, Rel. DESEMBARGADOR FEDERAL NÉVITON GUEDES, PRIMEIRA 
Para melhor vislumbrar a repercussão previdenciária concreta e individualizada que emana da transexualidade, mostra-se crucial subdividir o contexto fático decorrente da alteração do Assento da pessoa constante do RCPN, em duas situações distintas:

PRIMEIRA: ao autorizar a mudança de sexo, o Magistrado competente adota o critério binário de gênero, alterando para o sexo masculino as pessoas biologicamente pertencentes ao sexo feminino, e para o sexo feminino as pessoas biologicamente pertencentes ao sexo masculino; ou

SEGUNDA: diante do livre convencimento do Magistrado, porquanto a parte pode não se reconhecer como pertencente obrigatoriamente ao gênero masculino ou feminino, decidir pela modificação do sexo biológico, para constar a pessoa como pertencente a um TERCEIRO GÊNERO, seja a identificando como 'transexual', pertencente a gênero neutro ou indefinido. Tal possibilidade, conforme ressaltado no Tópico 2, além de possuir respaldo no direito alienígena (Alemanha, Austrália e Índia), já o foi inclusive reconhecida pela Jurisprudência nacional.

Por opção metodológica, visando reduzir complexidade à análise, tais hipóteses serão tratadas em tópicos próprios, porquanto comportam soluções diversas, sendo a primeira hipótese aprofundada no tópico 3.2.1 (SOLUÇÃO GERAL), e a segunda no tópico 3.2.2 (SOLUÇÃO ESPECÍFICA).

Diante de uma reflexão jurídica acerca do tratamento previdenciário a ser dado aos transexuais que tiveram o seu Registro civil alterado, nas hipóteses em que a Lei traz uma diferenciação nos critérios e nos requisitos - para fins de concessão dos benefícios - pautada no gênero sexual do segurado, chegou-se a quatro possíveis soluções gerais hipotéticas:

$1^{a}$ (PRIMEIRA) - Preservação do critério biológico: essa solução hipotética se fundaria - sobretudo: A) na ideia da fragilidade física da mulher em comparação aos homens, para chegar-se à conclusão de que a alteração do Registro Civil de transexual (para qualquer dos três gêneros eventualmente admitidos) não pode influenciar o âmbito previdenciário dos direitos do contribuinte. Isso

TURMA, e-DJF1 p.88 de 13/05/2014. Disponível através do portal: http://arquivo.trf1.jus. br/ PesquisaMenuArquivo. asp?p1 $=254829620024013400 \& p A=200234000255408 \& p N=25$ 4829620024013400 . Acessado em: 09/11/2016. 
porque o homem transexual (biologicamente pertencente ao sexo feminino), ainda que submetido a tratamento hormonal, dificilmente chegaria a mesma condição física do homem no seu estado biológico natural, e a mulher transexual (biologicamente pertencente ao sexo masculino), dificilmente chegaria a ter a mesma suposta fragilidade física da mulher no seu estado biológico natural; B) na proteção a segurança jurídica, porquanto a tutela da personalidade e direito à identidade da pessoa humana não pode ser motivo apto a influenciar - positiva ou negativamente - a aplicabilidade dos requisitos necessários à concessão dos benefícios previdenciários, o que abriria margem à alteração do Registro Civil com o espoco de obter o tratamento previdenciário mais benéfico, ou, ao contrário, restringindo àqueles que passarão a ter um tratamento mais gravoso.

$2^{a}$ (SEGUNDA) -Tempus regit actum $^{50}$ : Esta solução se fundaria no princípio segundo o qual o direito ao benefício previdenciário regula-se pela lei e condições vigentes ao tempo em que perfectibilizados os pressupostos necessários à concessão do benefício, momento no qual surge o direito adquirido. Posição respaldada, inclusive, pela Jurisprudência consolidada do Superior Tribunal de Justiça e Supremo Tribunal Federal. Partindo dessa solução, um tanto pragmática e legalista, porém de extrema valia ao direito previdenciário, levar-se-ia em consideração o sexo ou gênero sexual da pessoa ao tempo em que formalizado o pedido de concessão do benefício previdenciário, julgando-se o cumprimento dos requisitos necessários ao seu deferimento, à luz da condição sexual vigente ao tempo do requerimento.

Exemplificando: uma mulher transexual (biologicamente pertencente ao sexo masculino), que teve o seu nome e sexo alterados no Assento constante do RCPN, quando tinha 59 (cinquenta e nove) anos de idade, a partir desse critério, uma vez preenchidos os demais requisitos (filiação, carência, etc.), poderia solicitar, ao completar 60 (sessenta) anos de idade, pedido de Aposentadoria por idade, na forma do Art. vide art. 201, §70, II, CF.

$3^{a}$ (TERCEIRA) - Critério proporcional misto: visando a uma solução intermediária, este critério, por nós assim denominado, funda-se na natureza 50 AMADO, Frederico. Direito Previdenciário. 7. ed. Salvador/BA: Editora JusPodivm, 2016, p. 147. 
jurídica constitutiva da Sentença que autorizou a alteração do estado civil da pessoa, em decorrência da mudança de sexo, cuja eficácia em face de terceiros opera-se a partir da averbação no Registro Civil da pessoa, com propagação como regra - irretroativa (ex nunc) dos seus efeitos. Nessa toada, o período de contribuição e a idade do segurado seriam calculados de acordo com o seu sexo biológico, proporcionalmente, até o instante preciso em que se operou a eficácia constitutiva da mudança, momento no qual a repercussão jurídica do novo gênero sexual passaria a operar para todos os efeitos de direito, calculando-se o período remanescente de acordo com esta nova condição de gênero.

Exemplificando: um homem transexual (biologicamente pertencente ao sexo feminino), que teve alterado o seu Assento constante do RCPN em decorrência de mudança de nome e sexo, que já havia contribuído (enquanto ainda do sexo feminino), por 20 (vinte) anos (equivalente a $2 / 3$ ou $66,6666 \%$ do período aquisitivo da aposentadoria por tempo de contribuição para mulheres), a partir desse critério, necessitaria ainda contribuir pelo período equivalente a cerca de 11 anos e 241 (duzentos e quarenta e um) dias (cerca de 8 meses), equivalente a 1/3 ou 33,3333\% do período aquisitivo da aposentadoria por tempo de contribuição para homens, para aposentar-se na forma do Art. 201, § $7^{\circ}$, I, da CF, ao totalizar 31 anos e 8 meses de contribuição. No caso de aposentadoria por idade, levarse-ia em consideração - proporcionalmente - a idade que possuía ao tempo do efeito constitutivo da alteração do sexo perante o RCPN.

$4^{a}$ (QUARTA) - Critério mais benéfico: Esta última solução hipotética se assenta nos primados da igualdade material, solidariedade, justiça social e fim social projetado pela norma, a partir de um exercício hermenêutico pautado na tutela da dignidade da pessoa humana, individual e socialmente considerada. Se a diferenciação de idade entre homens e mulheres, para fins previdenciários, tem por objeto (fim social) compensar a menor oportunidade de trabalho às mulheres, fruto de histórica e ilegítima discriminação, mesmo raciocínio se aplicaria aos transexuais (independentemente do gênero fruto da alteração), que - como regra - vivem à margem da sociedade, e são objeto de grave e radical exclusão discriminatória, ainda hoje, por parte da sociedade. Cumpre ao Estado, à luz da solidariedade (Preâmbulo, Art. $3^{\circ}$, inciso I, CF) e Justiça social (Preâmbulo, Art. 
$3^{\circ}$, inciso I, e Art. 193, CF), encontrar meios aptos a compensar as desigualdades sociais, primando pela não discriminação e inserção desse conjunto de pessoas no âmbito das relações sociais.

Exemplificando: a partir desse critério, a toda pessoa transexual, que tenha alterado o seu Assento constante do RCPN, seria atribuído o mesmo tratamento conferido às Mulheres para efeitos previdenciários.

\section{SOLUÇÃO GERAL - ALTERAÇÃO DE SEXO CONFORME GÊNERO BINÁRIO (HOMEM E MULHER)}

Importante considerar, desde já, acredita-se que a primeira solução hipotética aduzida no item anterior (manutenção do sexo biológico para fins previdenciários) não se coaduna - em nenhuma hipótese - aos valores, aos princípios e às regras que compõem todo o ordenamento jurídico. Primeiro, diante do fato de a pessoa não poder receber um tratamento jurídico contraditório por parte do Estado. Se este a reconheceu como pertencente a um gênero sexual, deve respeitar os efeitos decorrentes desta constatação. Os direitos da Personalidade, corolários da tutela à dignidade humana, têm repercussão em toda e qualquer espécie de relação jurídica.

Acredita-se que uma suposta fragilidade física da mulher, diante do contexto social de trabalho atual, não pode ser fundamento bastante a afastar a repercussão jurídica derivada da alteração do gênero sexual, primeiro pelo fato de que a realidade de trabalho hoje não tem o seu exercício pautado na força física, ao contrário, vive-se a era da automação e da valorização do conhecimento (técnico, prático e científico), considerações essas ratificadas pela maior expectativa de vida das mulheres em comparação aos homens.

Nesse diapasão, vale lembrar o posicionamento Jurisprudencial mais recente, que caminha no sentido de reconhecer aos Transexuais o direito de alterar o seu gênero sexual constante do RCPN sem que tenha sido realizada cirurgia ou qualquer procedimento tendente a alterar as características morfológicas e fisiológicas do próprio corpo, através do processo de transexualização. Tal solução, 
que se acredita - inclusive - esteja em sintonia aos valores inerentes à tutela da dignidade e da personalidade da pessoa, dentre eles o do direito ao próprio corpo, honra e imagem, deve ser vista com cautela, não podendo, contudo, ser utilizada - propositalmente - com o objetivo desvirtuado de obtenção de um tratamento previdenciário mais benéfico, sob pena de incorrer-se em um desvio de finalidade, que não se coaduna com os fins pretendidos pelas normas jurídicas. Tal situação, de toda sorte, consoante repisado, deve ser aferida concretamente, não podendo ser utilizada como fundamento de restrição abstrata da tutela de direitos inafastavalmente ligados à dignidade humana.

Noutro foco, em que pese o segundo critério esposado no item anterior (tempus regit actum), seja de aplicabilidade recorrente no âmbito do direito previdenciário, e possua consolidado respaldo na Jurisprudência, mostrase suscetível de gerar injustiças concretas, distorções e abusos, tal como não soluciona a questão da pessoa que tenha alterado o seu Assento constante do RCPN, conforme a concepção do terceiro gênero (sendo a pessoa registrada como transexual, gênero neutro ou indefinido).

Como exemplo das possíveis distorções e injustiças que seriam ocasionadas pela adoção do critério 'Tempus regit actum', pode-se imaginar a situação de um homem transexual (biologicamente pertencente ao sexo feminino), que, com 29 (vinte e nove) anos de contribuição, alterou o seu Assento constante do RCPN para assumir o gênero sexual masculino. Nesse caso, caso adotado pura e simplesmente o critério 'Tempus regit actum', esta pessoa precisaria ainda contribuir por mais 6 (seis) anos, enquanto que, antes de promovida dita alteração precisaria de apenas 1 (um) ano de contribuição para perfectibilizar o direito à aquisição do benefício. Acredita-se que tal solução não é equilibrada. Outros exemplos poderiam ser aduzidos.

Acredita-se que, enquanto não sobrevier Legislação explicitando detidamente o tratamento jurídico previdenciário a essas situações, deve-se encontrar uma solução simples, equilibrada, não discriminatória, e ao mesmo tempo que seja isonômica do ponto de vista formal, visando não conferir discricionariedade axiológica aos funcionários públicos que integram o INSS, competentes por julgar o direito à aposentação dos segurados. 
Por essa razão, enquanto não sobrevier Lei específica sobre o tema, acredita-se que, como solução geral, deva ser adotado o Terceiro Critério - 'proporcional misto', quando a alteração do Assento constante do RCPN observar o gênero binário (homem e mulher), porquanto melhor se coaduna aos valores, aos princípios e às regras que ditam a hermenêutica jurídica do ordenamento pátrio.

Vislumbra-se o Critério 'proporcional misto' como dotado de maior razoabilidade e proporcionalidade, observando e respeitando o efeito constitutivo da decisão judicial que autorizou a alteração do Estado da pessoa (e seu efeito ex nunc) e cuja aplicabilidade no âmbito do direito previdenciário não exige discricionariedade axiológica, tampouco sua aplicabilidade demandaria maior indagação, utilizandose a prova documental que comprova o exato instante que perfectibilizada a eficácia erga omnes do efeito constitutivo (averbação no RCPN).

Tal critério não é suscetível de gerar tratamento discriminatório ilegítimo, porquanto observa e respeita o Estado civil da pessoa na exata proporção em que externalizado. Outrossim, mostra-se mais afinado à concretização da justiça do caso concreto, respeitando a isonomia material, tal como os equilíbrios financeiro e atuarial da previdência, gerando maior previsibilidade orçamentária dos efeitos decorrentes da alteração do gênero sexual, porquanto operam irretroativamente (ex nunc).

De toda sorte, esta Solução Geral mostra-se inapta a resolver a questão da pessoa que tenha alterado o seu Assento no RCPN conforme a concepção do terceiro gênero. Pois seja, a pessoa que mudou o seu sexo biológico (homem ou mulher) e passou a constar no Assento constante do RCPN como detentora de um terceiro gênero (transexual, gênero neutro ou indefinido) não tem esta hipótese resolvida pela Solução Geral.

É preciso encontrar uma solução específica para esta última hipótese.

\section{SOLUÇÃO ESPECÍFICA - ALTERAÇÃO DE SEXO CONFORME TERCEIRO GÊNERO (TRANSEXUAL, GÊNERO NEUTRO OU INDEFINIDO)}

Pesquisas apontam que as pessoas transexuais possuem um índice de evasão escolar que ultrapassa os $70 \%$ (setenta por cento) ${ }^{51}$ e o número de transexuais 51 FACHIN, Luiz Edson. Revista Brasileira de Direito Civil. Vol. 1, Julho/2014, p.61. 
com vínculo formal de trabalho perfaz cerca de $10 \%$ (setenta por cento) ${ }^{52}$. Tais dados denotam, diante do grau de exclusão social a que estão submetidas, e do reflexo da falta de aperfeiçoamento técnico e científico decorrente do altíssimo índice de evasão escolar, a dificuldade de inserção dessas pessoas no mercado de trabalho.

Diante desse contexto, na hipótese de a pessoa alterar o seu sexo constante do Assento de Nascimento, em decorrência do reconhecimento judicial da existência de identidade de gênero sexual diverso do sexo biológico, e com isso assumir a condição de um Terceiro gênero (gênero neutro, indefinido ou transexual propriamente dito), não se pode olvidar do fato de que terão maiores dificuldades de inserção no mercado de trabalho.

Nesse diapasão, exsurge a pertinência do quarto critério hipotético - o do tratamento mais benéfico. Atribuir ao transexual o tratamento previdenciário mais benefício, diante desse contexto fático, ao contrário de conferir-lhe privilégio ilegítimo, observa a proteção concreta da dignidade da pessoa humana e respeita a igualdade material, Justiça social e solidariedade, porquanto considera a vulnerabilidade social e a maior dificuldade de inserção dessas pessoas no mercado de trabalho.

Se utilizado como único critério, não gerará - do ponto de vista prático maior complexidade administrativa para fins de concessão do benefício, contudo, dá margem a abusos e distorções, o que não é objetivado pelo fim social da norma. Desta forma, como dito no item anterior, enquanto não sobrevier Lei específica regulando essas situações, deve-se encontrar uma solução equilibrada, não discriminatória, e que não afete os princípios previdenciários do equilíbrio financeiro e atuarial, tal como não colida com a característica irretroativa dos efeitos constitutivos da Sentença que alterou o estado civil da pessoa.

Assim, acredita-se que o critério 'mais benéfico' deverá ter sua aplicabilidade cumulada com o critério 'proporcional misto', aplicando-se o tratamento conferido 52 VASCONCELLOS, Luciana Teixeira de. Travestis e Transexuais no Mercado de Trabalho. Artigo apresentado no mês de agosto do ano de 2014, perante o X CONGRESSO NACIONAL DE EXCELÊNCIA EM GESTÃO. Disponível através do portal: http://www.inovarse.org/sites/ default/files/T14_0409.pdf, acessado em 22/11/2016. 
às mulheres (mais benéfico) pelo período (de idade ou tempo de contribuição) remanescente necessário à aquisição do benefício, iniciado após a averbação da alteração formal do estado civil da pessoa no RCPN.

Por exemplo, seguindo esta solução específica, a uma pessoa biologicamente pertencente ao sexo masculino, que alterara o seu sexo aos 30 (trinta) anos de idade, período este equivalente a cerca de $46,15600 \%$ do período aquisitivo necessário à concessão do benefício de aposentadoria por idade para homens, uma vez mudando o seu sexo constante do RCPN para um Terceiro gênero (gênero sexual neutro, indefinido ou transexual propriamente dito), precisaria ainda cumprir o equivalente a 53,844\% do período aquisitivo da Aposentadoria por idade para mulheres (mais benéfico), e que, seguindo esse critério de cálculo, teria perfectibilizada a aquisição do seu direito à aposentadoria ao atingir 62 (sessenta e dois) anos e cerca de 112 (cento e doze) dias de vida (quatro meses), observados os demais requisitos (filiação, contribuição e período de carência).

Já na hipótese de uma pessoa biologicamente pertencente ao sexo feminino, que alterara o seu Assento constante do RCPN para assumir a condição de um Terceiro gênero sexual, terá preservada a integralidade da sua condição de tratamento previdenciário, afinal já detinha o tratamento mais benéfico antes mesmo da alteração.

Acredita-se que tais soluções - esposadas com este trabalho - sejam aptas a resolver a repercussão previdenciária decorrente da alteração civil do sexo de pessoa transexual.

\section{CONSIDERAÇÕES FINAIS}

Diante da construção jurídica esposada no decorrer do presente artigo, pôdese chegar às seguintes conclusões:

1. Os direitos da personalidade, positivados no Código Civil pátrio, tutelam o direito de pessoa transexual à alteração do prenome e sexo constantes do Assento de Nascimento no RCPN, a fim de compatibilizá-los à identidade de gênero sexual diverso do sexo biológico. 
2. Somente aos transexuais classificados como primários, no caso, aqueles que manifestam convicção precoce, impulsiva e permanente de pertencer ao gênero sexual oposto àquele presumido pelo sexo biológico, é reconhecido o direito a submeter-se ao processo médico de redesignação sexual, com o conjunto de intervenções que lhe são decorrentes. Aos transexuais classificados como Secundários, também denominados de falsos transexuais ou transexuais homossexuais, não é reconhecido o direito à redesignação sexual, porquanto não manifestam interesse permanente em possuir características do sexo oposto.

3. O ordenamento jurídico brasileiro adota implicitamente a concepção binária de gênero (Art. $5^{\circ}$, inciso I, CF), em que pese o direito alienígena caminhe no sentido de reconhecer a existência de um terceiro gênero sexual.

4. O posicionamento jurisprudencial mais recente caminha no sentido de reconhecer o direito à alteração do gênero sexual no Assento de Nascimento constante do Ofício do RCPN, independentemente de ter a pessoa transexual sido previamente submetida ao processo de alteração artificial do sexo, através do conjunto de medidas e procedimentos admitidos pelo Conselho Federal de Medicina e Ministério da Saúde.

5. A alteração do estado civil da pessoa, em decorrência do reconhecimento de identidade de gênero sexual diverso do sexo biológico, possui natureza constitutiva, e depende - inexoravelmente - da propositura de Ação de jurisdição voluntária e sentença constitutiva, que produzirá os efeitos - irretroativamente a contar da averbação da mudança no Assento da pessoa junto ao RCPN.

6. A mudança do estado civil individual da pessoa, decorrente da alteração civil do gênero sexual, não tem sua repercussão jurídica adstrita pura e simplesmente às relações afetas naturalmente aos direitos da personalidade (direito à identidade, nome, opção sexual e relações familiares), mas sim a toda e qualquer relação em que o gênero sexual importe em tratamento diferenciado, em respeito à isonomia, vedação a tratamento contraditório pelo estado, vedação à discriminação ilegítima, e tutela material da dignidade humana, dentro desse âmbito abrangidas às relações afetas ao direito previdenciário. 
7. Em respeito à segurança jurídica, e observando o princípio da unitariedade e da indivisibilidade dos elementos atinentes ao estado civil da pessoa, enquanto não reconhecida a posse de estado civil diverso do constante do Registro Civil da pessoa, decorrente da inadequação entre o gênero sexual e o sexo biológico, através de Sentença judicial prolatada em Processo de Jurisdição voluntária, culminada com a averbação da alteração do gênero sexual no respectivo Assento da pessoa no RCPN, não poderá a pessoa pretender tratamento previdenciário diferenciado em função da transexualidade.

8. Enquanto não sobrevier Lei regulando o tratamento previdenciário a ser dado às pessoas que promoveram a alteração civil do gênero sexual, propõemse as seguintes soluções:

8.1 Como regra geral, para os casos em que a alteração civil do gênero sexual observar o gênero binário (homem e mulher), deva ser adotado o critério aqui denominado de 'Proporcional misto', calculando-se o período de idade ou tempo de contribuição - de acordo com o sexo biológico da pessoa, proporcionalmente, enquanto não promovida a Averbação da alteração do gênero sexual no RCPN, e, pelo período remanescente, de acordo com esta nova condição de gênero. Para verificar a perfectibilização do cumprimento do período necessário à concessão do benefício, as proporções em cada um dos critérios devem ser somadas.

8.2 Como regra específica, para os casos em que - com a alteração gênero sexual - a pessoa assumir a condição de um terceiro gênero (neutro, indefinido ou transexual propriamente dito) perante o RCPN, deve ser adotado o critério 'proporcional misto', calculando-se o período de idade ou tempo de contribuição - de acordo com o sexo biológico da pessoa, proporcionalmente, enquanto não promovida a Averbação da alteração do gênero sexual no RCPN e pelo período remanescente (em que assumiu a condição ternária de gênero) será aplicado o critério mais benéfico, pois seja, o tratamento previdenciário conferido às mulheres para fins de aposentação.

9. Por fim, encerra-se o presente artigo acreditando que, em que pese se esteja diante do início de uma preocupação em tutelar adequadamente as 
pessoas reconhecidas como transexuais, ainda não o são medidas que satisfazem por completo a integração delas perante a sociedade, em vista da existência de um ordenamento jurídico - fruto de construção histórica paulatina - ainda hoje pautado por premissas que polarizam direitos à luz da condição sexual, cada vez mais geradora de repercussão jurídica e efeitos inadequados. A distinção jurídica entre os sexos deverá ceder espaço a elementos objetivos legítimos de discriminação entre as pessoas, destinados a dar concreção aos primados constitucionais da igualdade material, solidariedade e justiça social.

\section{REFERÊNCIAS}

AMADO, Frederico. Direito Previdenciário. 7. ed. Salvador/BA: Editora JusPodivm, 2016.

AMARAL, Francisco. Direito Civil. Introdução. 5. ed. Rio de Janeiro: Editora Renovar, 2003.

BARROSO, Luís Roberto. Interpretação e Aplicação da Constituição. 3. ed. São Paulo: Editora Saraiva, 1999.

BRASIL, Ministério da Saúde. Portaria n².803, de 19/11/2013. Disponível pelo site: http://bvsms. saude.gov.br/bvs/saudelegis/gm/2013/prt2803_19_11_2013.html. Acessado em: 17/10/2016.

CASSETTARI, Christiano (Coordenação). Registro Civil das Pessoas Naturais. Vol. I. São Paulo: Editora Saraiva, 2014.

DIDIER JR, Fredie. Curso de Direito Processual Civil. 10. ed. Vol 1. Salvador/BA: Editora JusPodivm, 2008.

DINIZ, Maria Helena. Dicionário Jurídico. Vol. IV. São Paulo: Editora Saraiva, 2008.

DINIZ, Maria Helena. Curso de Direito Civil Brasileiro. 24. ed. São Paulo: Editora Saraiva, 2007.

FACHIN, Luiz Edson. Revista Brasileira de Direito Civil. Vol. 1, Julho/2014.

GOES, Hugo. Manual de Direito Previdenciário - Teoria e questões.10. ed. Rio de Janeiro: Editora Ferreira, 2015.

GONÇALVES, Camila de Jesus Mello. A transexualidade sob a ótica dos direitos humanos: uma perspectiva de inclusão. Tese de Doutorado apresentada perante a Faculdade de Direito da Universidade de São Paulo - USP, ano de 2012, p. 55-56. Tese integral disponível 
através do portal: http://www.teses.usp.br/teses/ disponiveis/2/2140/tde-04032013-105438/ pt-br.php. Acessado em: 20/09/2016.

HOSPITAL KAMOL. Banguecoque, Tailândia. Especializado em técnica de transsexualização. Disponível pelo site: http://www.kamolhospital.com/pt/FTM-surgery/ reconstru\%C3\%A7\%C3\%A3o-genital. Acessado em 16/10/2016.

IPEA - Instituto de Pesquisa econômica aplicada. Mulheres e trabalho: breve análise do período 2004-2014. Nota técnica n 24. Brasília, 03/2016. Disponível através do portal: http://www. ipea.gov.br/portal/index.php?option=comcontent\&viewarticle\&id $=2731$. Acessado em: 08/11/2016.

JESUS, Jaqueline Gomes de. Orientações sobre a população transgênero: Conceitos e termos. Artigo publicado, ano de 2012, p. 7. Núcleo de Estudos e Pesquisas em gênero e Sexualidade da Universidade Federal de Goiás. Disponível através do site: https://www. sertao.ufg.br/up/16/o/ORIENTA\%C3\%87\%C3\%95ES_ POPULA\%C3\%87\%C3\%83O_TRANS. pdf?1334065989. Acessado em: 28/09/2016.

KLABIN, Aracy Augusta Leme. Aspectos jurídicos do Transexualismo. Artigo Publicado na Revista da Faculdade de Direito da Universidade de São Paulo, V. 90, ano de 1995.

MARQUES, Cláudia Lima. Diálogo das fontes. Do conflito à coordenação de normas no direito brasileiro. 1. ed. São Paulo: Editora RT, 2012

MELLO, Celso Antônio Bandeira de. O conteúdo jurídico do princípio da igualdade. 3. ed. 24ª Tiragem. São Paulo: Malheiros editores, 2015.

MENDES, Gilmar Ferreira; BRANCO, Paulo Gustavo Gonet. Curso de Direito Constitucional. São Paulo: Editora Saraiva, 2012.

PEREIRA, Rodrigo da Cunha (Organizador). Tratado de Direito das Famílias. 1. ed. Belo Horizonte: Instituto Brasileiro de Direito de Família - IBDFAM, 2015.

PELUSO, Cesar. Código Civil Comentado. 4. ed. São Paulo: Editora Manole, 2010.

REALE, Miguel. Teoria tridimensional do direito - situação atual. 5. ed. São Paulo: Editora Saraiva, 1994.

RIBEIRO, Benedito Silvério. Análise dos Casos que Implicam Alterações no Registro Civil. In: Serviços Notariais e de Registro. $1^{\circ}$ Simpósio Nacional de Serviços Notariais e Registrais de São Paulo, 09/1996. 
ROSENVALD, Nelson; FARIAS, Cristiano Chaves de. Curso de Direito Civil. Vol. 1. 13a ed. São Paulo: Editora Atlas, 2015.

ROWEDER, RAINNER JERÔNIMO. O terceiro gênero: Políticas públicas e mecanismos jurídicos de valorização da dignidade humana pelo viés do gênero. Dissertação de Mestrado apresentada perante o Programa de Pós-Graduação da Faculdade de Direito da Universidade Federal de Minas Gerais - UFMG, 2015, p. 58; 60-61; 63. Disponível através do portal: http://www. bibliotecadigital.ufmg.br/dspace/ handle/1843/BUBD-A3WFAK. Acessado em: 01/11/2016.

SAADEH, Alexandre. Boletim ICAPS, junho de 2005, n²31, p.8. Disponível através do site: http:// www.icaps.org.br/wp-content/uploads/2015/12/Icaps-231.pdf. Acessado em: 28/09/2016.

SCHREIBER, Anderson. Direitos da Personalidade. 2. ed. São Paulo: Atlas, 2013.

TARTUCE, Flávio. Manual de Direito Civil. 3. ed. São Paulo: Editora Método, 2013.

VASCONCELLOS, Luciana Teixeira de. Travestis e Transexuais no Mercado de Trabalho. Artigo apresentado no mês de agosto do ano de 2014, perante o X CONGRESSO NACIONAL DE EXCELÊNCIA EM GESTÃO. Disponível através do portal: http://www.inovarse.org/sites/ default/files/T14_0409.pdf. Acessado em: 22/11/2016.

VEIGA, Ana Paula. Assexualidade. Artigo 752. Disponível no site: https://www.abcdasaude. com.br/sexologia/assexualidade. Acessado na data de 06/10/2016.

VENOSA, Silvio de Salvo. Direito Civil. 11. ed. Vol. I. São Paulo: Editora Atlas, 2011.

Recebido em: out/2016

Aprovado em: dez/2016 